\title{
RELIGIÃO EM TEMPOS DE GLOBALIZAÇÃO E TRANSNACIONALIZAÇÃO RELIGIOSAS: A PRODUÇÃO DA CRENÇA E A REINVENÇÃO DE TRADIÇÃO A PARTIR DO CONTATO INTERCULTURAL ENTRE DIFERENTES SUJEITOS E INSTITUIÇÕES
}

Mauro Meirelles ${ }^{1}$

Resumo: O presente texto versa sobre o processo de globalização e transnacionalização religiosas a partir de pesquisa de campo realizada em três países da América Latina, a saber, o Brasil, o Uruguai e a Argentina. Neste sentido, a partir de entrevistas realizadas com pastores evangélicos e lideranças religiosas ligadas às religiões de matriz africana nos três países busca-se discutir a forma como elementos provenientes de religiosidades diversas, constituídas historicamente em áreas geográfico-culturais distintas, produzem novas formas de experimentação e vivência do religioso para além de suas fronteiras nacionais de origem. Sobretudo, enfoca-se o modo como tanto as religióes de matriz pentecostal, neopentecostal como aquelas de origem africana e brasileira, ao inserir-se em contextos nacionais diversos daquele de seu surgimento acabam por absorver elementos da cultura local, reinventam a tradição e a própria crença religiosa em função do público a que se destina sua mensagem e/ou prática religiosa.

Palavras-chave: Transnacionalização religiosa; Pentecostalismo e religiōes afrobrasileiras; Sincretismo e hibridismo; Mimetização.

Abstract: This paper analyzes the process of religious globalization and transnationalization from field research conducted in three Latin American countries, namely Brazil, Uruguay and Argentina. In this regard, from interviews with evangelical pastors and religious leaders connected to religions of African origin in the three countries this work seeks to discuss how elements coming from several religiousness, historically constituted in different geographic and cultural areas,

1 Doutor em Antropologia. Pesquisador do Núcleo de Estudos da Religião (NER) e Professor na Unilasalle. 
produce new forms of living the religious experience beyond its originary national borders. Especially, it focuses on how religions of Pentecostal and Neopentecostal matrix, as those of African and Brazilian origin, are inserted in different national contexts and end up absorbing elements of local culture, reinventing tradition and the belief religious in function of the intended audience to whom their message and /or religious practice is destined.

Keywords: Religious transnationalization; Pentecostalism and afro-brazilian religions; Syncretism and hybridity; Mimicry.

\section{INTRODUÇÃO}

Num mundo cada vez mais interconectado por redes de computadores e meios de locomoção cada vez mais rápidos e eficazes, atravessar fronteiras e aportar em outras cidades, países e continentes exige cada vez menos tempo e investimentos de capital por parte daqueles que se aventuram nessa seara. Da mesma forma, torna-se cada vez mais acessível a pessoas localizadas em diferentes partes do mundo o acesso a informações e relatos de experiências das mais diversas, socializadas por pessoas que através do uso da internet compartilham conhecimentos, saberes e experiências em sites pessoais, blogs e redes sociais, onde, o único requisito é o conhecimento básico da língua franca da rede mundial de computadores - o inglês.

Assim, se hoje em dia, no que se refere ao campo econômico, pode-se, com o uso da rede mundial de computadores, comprar produtos americanos produzidos na China em lojas europeias e recebê-los no Brasil de modo que, para além das transaçôes de caráter estritamente econômico, também é possível a indivíduos localizados em diferentes partes do mundo, por meio deste mesmo suporte, realizar a troca de bens simbólicos e culturais. Tais bens, sem valor discreto definido a priori, na medida em que não nos é possível mensurar o trabalho nele cristalizado e externos ao mercado de trocas financeiras e econômicas, uma vez que têm seu valor definido $a$ posteriori em função da agregação de outros tipos de capitais (de prestígio, 
de consagração etc.) constituem aquilo que Bourdieu (2004) denomina de uma economia de trocas simbólicas.

Nesta economia, em que o valor estritamente econômico é deixado de lado e dissimulado em função da imaterialidade constitutiva dos bens que nele circulam, seu valor é dado na razão inversa daquela constitutiva do campo econômico, mas que, em função de seu pedigree e da circulação em mercados específicos, ganha valor agregado passível de conversão em outros tipos de capitais (Price, 2000). Ainda nesta direção tanto Hobsbawn e Ranger (1984) quanto Dundes (1985) destacam que tradiçóes podem ser inventadas por meio de narrativas dispersas, de fatos isolados, de translocações e apropriações que, esvaziadas de seu referencial de origem e organizadas e territorializadas sobre uma base comum a um dado conjunto de pessoas, acabam por se constituir em um novo campo semântico, em que, estes, assumem valores e conteúdos míticos-imagéticos diversos daquele que possuíam em sua origem.

Isso posto, destaca-se que tanto o campo artístico quanto o político, o científico e o religioso constituem-se em um mercado de trocas simbólicas extremamente rico e particular que cabe ao antropólogo desvendar através do desvelamento de sua dinâmica e lógica constitutivas. Pois, é nele - nesse campo circunscrito de interaçõos - que os diversos atores e instituições sociais estão inseridos. E, desse modo, estão submetidos a normas, crenças e valores inerentes a esse espaço circunscrito de interação e circulação de bens simbólicos. É, portanto, no sentido de explorar essas particularidades do campo religioso no interior dos três países supracitados e de pensar o processo de hibridização e sincretização de diferentes religiosidades que, a partir do fluxo transnacional de lideranças religiosas evangélicas e afro-brasileiras, buscase realizar uma cartografia desse movimento e das dinâmicas que fazem desse campo tão particular um lócus privilegiado para o entendimento das múltiplas instâncias constitutivas daquilo que, no âmbito dos estudos da antropologia da religião denominou-se de campo religioso. 


\section{A CONSTITUIÇÃO DO CAMPO RELIGIOSO NO BRASIL, URUGUAI E NA ARGENTINA}

Embora Brasil, Uruguai e Argentina possuam situações bastante díspares acerca da forma como as diferentes religiōes se relacionam entre si e para com o Estado, seja atual, seja historicamente, no mínimo duas recorrências são observadas nos três países. Uma que aponta para a existência de diferentes formas de se relacionar entre si e para como o Estado e outra que revela certa recorrência no que tange à forma como lideranças religiosas afro-brasileiras e, outras, ligadas às igrejas pentecostais e neopentecostais relacionam-se com o Estado e, entre si, naquilo que Oro (1997) denomina de guerra santa, em que, para além de suas fronteiras de origem, reproduzem-se em terras estrangeiras aporias comuns a essas religiosidades quando em território brasileiro.

Ainda nesta direção, referindo-se ao campo religioso dos três países, Semán (2006) destaca que há, no Brasil, uma maior diversidade religiosa do que aquela observada nos outros dois países cisplatinos. De fato, dados constantes no censo de 2010 realizado no Brasil e naqueles compilados pelo CONICET (2008) relativos à Argentina e à Grande Buenos Aires (GBA), assim como em outros, relativos ao Uruguai e a Montevidéu, apresentados pelo Instituto Nacional de Estadística (ENHA, 2006), asseguram o acerto da afirmação feita por Semán, como se pode ver na tabela a seguir. 
Tabela 1 - Distribuição percentual das religiōes no Brasil, na Argentina e no Uruguai

\begin{tabular}{lcccccc} 
Religião & Brasil & POA $^{2}$ & Argentina & BsAs & Uruguai & MVD \\
\hline Católicos $^{3}$ & 64,99 & 64,29 & 76,5 & 69,1 & 47,1 & 43,1 \\
Evangélicos Históricos $^{4}$ & 4,03 & 5,22 & & & & \\
Evangélicos Pentecostais & 13,3 & 5,98 & & & 11,1 & 8,2 \\
$\begin{array}{l}\text { Outras igrejas evangélicas } \\
\text { sem vínculo institucional }\end{array}$ & 2,76 & 2,76 & 9,0 & 9,1 & & \\
Outras religiosidades evan- & 4,36 & 1,50 & & & & \\
gélicas & & & & & 23,2 & 23,3 \\
Espírita & 2,02 & 6,86 & - & - & - & - \\
Outras Cristãs & 0,77 & 0,88 & 2,1 & 1,4 & - & - \\
Umbanda & 0,52 & 6,26 & & & 0,6 & 1,0 \\
Budismo & 0,13 & 0,19 & & & - & - \\
Outras religiōes orientais & 0,17 & 0,23 & 1,2 & 2,3 & - & - \\
Candomblé & 0,09 & 0,19 & & & - & - \\
Judaísmo & 0,06 & 0,47 & & & 0,3 & 0,7 \\
Outras religiōes & 0,98 & 1,90 & & & 0,4 & 0,4 \\
Sem religião & 8,04 & 10,69 & 11,3 & 18,0 & 17,2 & 23,7 \\
Sem declaração & 0,34 & 0,00 & - & - & - & - \\
Não determinadas & 0,02 & 0,40 & - & - & - & - \\
\hline
\end{tabular}

Fonte: www.ibge.gov.br Tabela 1489; ENHA 2006; CONICET 2008

Compilação dos dados: Mauro Meirelles

${ }^{2}$ No caso do presente estudo, opto por compilar os dados referentes a Porto Alegre, por este ser o lócus privilegiado de minha pesquisa de campo e por ser a ela vinculada grande parte das minhas observaçóes etnográficas, sobre as quais teço meu argumento no decorrer do texto.

${ }^{3}$ Correspondente à soma percentual dos valores observados para os católicos ligados às Igrejas: Apostólica Romana, Apostólica Brasileira e Ortodoxa.

${ }^{4}$ Correspondente à soma percentual dos valores observados para as seguintes denominações evangélicas históricas: Igreja Batista, Igreja Adventista, Igreja Luterana, Igreja Presbiteriana, Igreja Metodista, Igrejas Congregacionais e outras igrejas evangélicas históricas não especificadas.

${ }^{5}$ Correspondente à soma percentual dos valores observados para as seguintes denominações evangélicas de origem pentecostal: Assembleia de Deus, Congregação Cristã no Brasil, Igreja Universal do Reino de Deus, Igreja do Evangelho Quadrangular, Deus é Amor, Maranata, Brasil para Cristo, Casa da Benção, Nova Vida e outras evangélicas pentecostais não especificadas.

${ }^{6}$ Correspondente à soma percentual dos valores observados para as seguintes denominações cristãs: Testemunhas de Jeová, Mórmons e outras denominações cristãs não especificadas. 
Segundo a Tabela 1, o que se observa é que, em termos percentuais, a Argentina é o país que apresenta o maior número de católicos, com $76,5 \%$, seguido do Brasil e do Uruguai, com 64,99\% e 47,1\%, respectivamente. Contudo, em termos absolutos, o número de católicos é maior no Brasil, dado o contingente populacional de cada um dos três países. No que se refere ao segmento evangélico, os dados apresentados mostram que, em termos percentuais, é no Brasil em que se observam os maiores valores (13,3\%), aos quais se segue o Uruguai $(11,1 \%)$ e a Argentina (9\%). Contudo, se considerarmos somente os números absolutos de fiéis deste segmento religioso, Uruguai e Argentina trocam de posição, passando esta última ao segundo lugar no ranking. Entre os afro-brasileiros, a situação não parece ser muito diferente e segue o observado nos dois segmentos anteriores.

Outro dado interessante a ser destacado é o fato de que, a exceção de Porto Alegre, nas outras duas capitais cisplatinas, o que observamos é uma pequena redução percentual no número de católicos e um pequeno acréscimo no número de evangélicos no caso do Buenos Aires. Contudo, se consideramos somente os números absolutos, será, novamente, Buenos Aires a cidade que deterá o maior número absoluto de fiéis católicos e evangélicos, em função da população total de cada uma dessas cidades. Isso posto, e dado o atual contexto religioso dos três países no que se refere à expansão das religiōes de matriz pentecostal e africana e os fluxos existentes entre eles, o que se observa é um avanço crescente das mesmas, que partem do Brasil em direção aos seus vizinhos latino-americanos, como já observado por Oro (1999), no que tange às religiōes do segmento afro-brasileiro, e por Meirelles (2009), no que tange aos pentecostais ligados à Igreja Batista Renovada (BRASA) e à Deus é Amor (DA).

Neste sentido, importa observar, também, a forma como estes diferentes estados nacionais relacionam-se com o religioso na medida em que no Brasil se opera em termos de uma certa compatibilização entre diferentes crenças que conseguem interagir de forma mais ou menos tranquila, ocupando, cada uma, o espaço a ela reservado. Movimento este semelhante ao que observamos no Uruguai nos dias 28 e 29 de abril de 2009, quando, em razão de evento promovido pelo Conselho Latino Americano de Igrejas (CLAI), 
reuniram-se no anexo do Senado lideranças de quase todos os segmentos religiosos montevideanos que buscaram, naqueles dois dias, sistematizar propostas de redução da intolerância religiosa e fornecer ao estado uruguaio algumas diretrizes e alguns valores que permitam a construção de uma sociedade mais justa e igualitária para todos. Isto, de certa forma, diverge do que ocorre no caso argentino em que o Estado se declara constitucionalmente católico, conforme assegura o artigo 2 de sua constituição, onde lê-se: "El Gobierno federal sostiene el culto católico apostólico romano".

Disso decorre a necessidade de retomarmos o debate sobre a secularização malgrado o caráter profundamente polissêmico que tal noção evoca, em função de diferentes escolas teóricas que pressupõem a presença da religião no espaço público como sendo ora uma "anormalidade histórica", ora um processo que num momento tende à "expansão" e, em outro, à "retração". Neste sentido, nos filiamos à segunda posição, a qual entende a secularização como um processo que nos permite pensar a relação entre religião e política em termos de uma "[...] arena pública mobilizada por atores e motivos religiosos", como coloca Semán (2006, p. 10).

Assim, entendida enquanto um processo (Sanchis, 2001), a ideia de secularização envolve, antes de mais nada, um conjunto de elementos que vinculam, em diferentes escalas, o político e o religioso. No plano mais amplo, temos a totalidade social e a forma como o político e o religioso se relacionam no âmbito daquilo que comumente chamamos de esfera pública e que, nos dias atuais, tem como ponto de partida principal a questão da laicidade do Estado.

Num plano intermediário, tal relação constitutiva do social é externa ao seu duplo de modo que tanto o campo religioso quanto o campo o político, no plano ideal, estariam separados e sua incidência sobre o conjunto da vida social ligado à forma como diferentes grupos, portadores de determinados valores a eles relacionados operam com ele e dele fazem uso enquanto um marco interpretativo do real que conduz/significa sua ação. É o caso, por exemplo, da entrada de diferentes atores sociais ligados ao campo religioso na esfera pública em razão de interesses vinculados a determinados segmentos religiosos que, neste espaço tradicionalmente tido como secular, acabam 
por encantá-lo através de formações discursivas e modos de ser e estar no político tributários ao que poderíamos chamar de uma identidade religiosa, como já escrevi em outro lugar (Meirelles, 2009).

Disso decorre um terceiro movimento, o qual, a partir dessa racionalização e autonomização das esferas política e religiosa, enfraquece os vínculos que os indivíduos possuem com instituiçóes tanto políticas quanto religiosas, a tal ponto que, em ambos os casos, o que se observa é uma recomposição de diferentes crenças e formas de estar no mundo a partir de múltiplos referenciais. $\mathrm{O}$ religioso profaniza-se, deixando cada vez mais de lado as coisas do espírito e adere à lógica do mercado, segmentando-se e tornando-se especialista na venda/oferecimento de diferentes serviços espirituais. O político, a exemplo de seu duplo, encanta-se e é cada vez maior a presença de candidaturas e pessoas que, para além dos interesses de toda a sociedade, transformam o palanque político em púlpito de predicação de valores religiosos, de intolerância e de defesa de interesses ligados ao seu grupo religioso de origem.

Isso posto e aceitando-se a proposição interpretativa que é oferecida por Semán (2006) e Pierucci (1998), a qual compreende o que hoje em dia chamamos de secularização/dessecularização enquanto um processo não acabado, observamos que tanto no âmbito teórico quanto naquele que emerge da observação da realidade empírica, alguns aspectos relacionados à sua própria ontologia e à forma como sobre ele nos debruçamos teoricamente devem ser retidos.

O primeiro deles é o fato de que esse processo ocorre no tempo e no espaço. No tempo, na medida em que há sempre um momento de onde partimos, de onde começamos a observar. No espaço, pois envolve um contexto social específico e que, desde o surgimento do primeiro Leviatã, já nos é possível circunscrevê-lo a uma determinada área de influência. E da conjunção destes dois aspectos emerge um outro, a singularidade de sua ocorrência. Singularidade expressa em sua ocorrência, uma vez que, essa, vincula-se a um determinado contexto espaço-temporal específico, à história constitutiva de uma nação, às relações existentes entre o estado e a 
igreja desde tempos outros, ao lugar que a religião e a política ocupam na vida das pessoas etc.

O segundo é aquele que sentencia o eterno porvir de uma morte anunciada. Finitude que nunca chega por completo, uma vez que, enquanto processo, ele nunca se encerra em si, oscilando entre dois polos distintos, o secular e o não secular. Neste sentido, tal processo estará sempre inacabado, mesmo em contextos nacionais específicos, em que se operou uma separação entre os campos político e religioso. É o caso, por exemplo, dos três países que aqui nos propomos a estudar, os quais, do ponto de vista das teorias da secularização, operaram, a partir de dispositivos constitucionais específicos, uma separação ou aproximação entre o religioso e o político. Contudo, os caminhos pelos quais se operou essa cisão ou aproximação constitucional entre os referidos campos não foram os mesmos e estiveram vinculados aos contextos nacionais específicos.

E um terceiro elemento, e não menos importante, que vincula esse processo à modernidade e à emergência de um ser humano autonomizado e racional que opera à margem dos dois polos. Um indivíduo que no âmbito privado professa uma fé e assume posiçôes de certa forma incoerentes com o modelo social no qual está inserido, mas que, quando na cena pública, opera sobre outra lógica, a partir dos operadores e das estruturas estruturadas existentes no campo no qual está inserido para usar a terminologia empregada por Bourdieu (2007). Neste sentido, deriva do exposto, conforme coloca Semán (2006), que a secularização no campo das instituições políticas e religiosas, nem sempre é acompanhada pela secularização das ideologias políticas e, muito menos, pela secularização/dessecularização dos eleitores e dos fiéis.

Disso deriva, também, que precisamos levar sempre em conta que a relação entre o político e o religioso, entendida enquanto um processo, resulta de uma relação de forças que operam no interior do Estado em que, no caso do Brasil, Uruguai e Argentina, fazem-se presentes no mínimo três movimentos, a saber: na Argentina, de se esvaziar o político de qualquer conteúdo ou valor religioso ligado ao catolicismo, este, tido até pouco tempo, como o elemento constituinte da identidade argentina (Semán; Martin, 
2006). No Uruguai, de levar para o político elementos e bandeiras de luta provenientes do campo religioso, de misturar-se ao político e adentrar na cena pública sem, contudo, violar a laicidade; e no Brasil, de uma crescente confessionalização do político, onde cresce cada vez mais o número de candidatos ligados as mais diferentes denominações religiosas, ao mesmo tempo em que o religioso aparece como co-constituinte do político, desde os tempos do Império.

Em especial, refiro-me à força que a religião e essas diferentes identidades políticas assumem, em cada um destes países, na conformação de um padrão de comportamento político mais consistente no Uruguai e na Argentina do que no Brasil. No caso da Argentina, o que se observa é uma imposição de valores, oriundos do catolicismo, tanto aos votantes quanto aos dirigentes políticos, de modo que tal imposição se dá fora do campo político e do momento eleitoral em específico. Já no Uruguai observa-se algo semelhante ao visto na Argentina; ou seja, notam-se identidades políticas bastante estáveis que se caracterizam por distinçōes políticas e ideológicas explicitamente laicas que demarcam de forma clara uma oposição entre o projeto iluminista radical e outro ligado a valores religiosos católicos.

Sobremaneira, para além do campo religioso em específico, o que se observa é um certo mimetismo, como veremos mais adiante, de uma religião para com a outra no que se refere ao campo político. No interior do campo religioso, também, em muitos casos, isso é observado naquilo que, por exemplo, a literatura especializada tem denominado de pentecostalização do catolicismo quando se refere ao movimento carismático, de reafricanização da religião quando se refere às religiōes afro-brasileiras dentro e fora do Brasil, entre outras. E, é, como diferentes elementos oriundos de culturas locais, do campo político, além de outros provindos de fora do campo africanista e evangélico, são incorporados de modo diverso às práticas religiosas das religiōes afro-brasileiras e neopentecostais que nos ocuparemos a seguir. 


\section{A PRODUÇÃO DA CRENÇA E A REINVENÇÃO DA TRADIÇÃO}

Como já escrevi em outro lugar (Meirelles, 2005), o que se observa é que as igrejas neopentecostais em geral e a Igreja Universal do Reino de Deus em específico se caracterizam por uma construção de sua práxis religiosa a partir da incorporação de elementos provindos de outras religiosidades. Nelas, o exorcismo, prática comum ao catolicismo desde muito tempo, é reinventado e levado para dentro dos templos, com a diferença que, neste caso, o elemento a ser exorcizado não é mais o diabo em si, mas sim, sua corporificação manifesta nas entidades que compõem o panteão das religiōes afro-brasileiras. O diabo, o senhor das trevas, cede lugar, nos templos, a pombas-gira e exus, tratados na literatura especializada como eguns ou espíritos inferiores que habitam os cemitérios e as ruas.

É comum, desse modo, num breve flanar pelas principais ruas de Montevidéu, Buenos Aires e Porto Alegre, encontrarmos templos religiosos neopentecostais especializados no lido com esses seres da noite oriundos, no caso, do Brasil, segundo a teoria êmica, dos terreiros de Batuque, Umbanda e Quimbanda, quando circunscrito do Rio Grande do Sul e das Casas de Candomblé, quando ampliamos o escopo para o resto do Brasil.

Já na Argentina, tal luta contra as entidades do mal se restringe especificamente àquelas que têm seu assento na Quimbanda e no Batuque, religiosidades bastante populares na periferia de Buenos Aires, onde, da mesma forma que no Brasil, o alvo são os exus e as pombas-gira. Contudo, no Uruguai, isso é um pouco diferente e as pombas-gira e os exus dão lugar a uma nova categoria semântica, esta, denominada de pestilento. Este último, um significante vazio que é dotado de sentido e semantizado nos cultos neopentecostais como a personificação do mal, dos males oriundos de trabalhos de bruxaria e/ou magia negra, equivalente sintático que faz referência às práticas religiosas afro-brasileiras ligadas ao Batuque e à Quimbanda.

Da mesma forma, referindo-se ao caso específico da Igreja Universal do Reino de Deus no Uruguai, observo que, em minha estadia em campo para tese de doutorado, em campanha realizada em maio de 2009, os pastores da referida igreja, utilizavam-se de batinas semelhantes àquelas usadas pelos 
padres da Igreja Católica, as quais traziam no peito uma cruz vermelha que lembrava os trajes usados nas primeiras missas realizadas pelos jesuítas no Brasil, como documenta a iconografia. O que de certo modo tendia, do ponto de vista do imaginário social, a aproximá-los do catolicismo, pois, tanto no Uruguai quanto na Argentina, as religiões neopentecostais são, em grande medida, na literatura antropológica e sociológica local, enquadradas na categoria seita. E, desse modo, somente são categorizadas como religiōes institucionalizadas aquelas oriundas do espectro católico tradicional (católicos apostólicos romanos e ortodoxos) e evangélico histórico (assembleianos, luteranos, presbiterianos, batistas, metodistas etc.), além de outras de origem étnica ligadas às comunidades judaicas, islâmicas, russa, chinesa etc.

O que se pode observar a partir disso é que, do ponto de vista prático, no que se refere especificamente ao campo religioso, há, tanto no contexto argentino quanto uruguaio, um processo de hibridização de elementos oriundos de outras religiosidades - em especial daquelas ligadas às religiōes afro-brasileiras - que são incorporados à prática ritual neopentecostal da Igreja Universal do Reino de Deus, do Uruguai e da Argentina. No caso do Brasil, da mesma forma, na IURD, o mesmo observa-se, todavia, dada a extensão territorial brasileira e pluralidade de religiosidades existentes, em alguns locais, principalmente na regiāo norte do Brasil, essa aporia se dará em relação à pajelança e a outras religiosidades populares, comum à região amazônica, por exemplo.

Outrossim, para além da Igreja Universal e, agora, fazendo referência à Igreja Encontros de Fé, esta, com sede em Porto Alegre e capitaneada pelo pastor Isaías Figueiró, processo semelhante é observado. Contudo, nesta, não serão elementos das religiōes afro-brasileiras que serão incorporados à prática religiosa e ritualística, e sim a ideia de guerra territorial. Esta, tributária ao 
modelo evangelístico utilizado pelo evangelista Carlos Annacondia ${ }^{1}$ em suas campanhas de salvação espiritual realizadas na Argentina. Em suas campanhas, Annacondia não personifica o mal, algo bastante comum entre algumas igrejas neopentecostais que constituem sua prática religiosa em função de aporia estabelecida com as religiōes afro-brasileiras, mas centra sua prática evangelística no combate ao mal territorializado. Este último, manifesto através de doenças, problemas psicológicos, financeiros, entre outros, nas pessoas que habitam uma determinada região.

Essa influência sobre o modelo evangelístico utilizado por Isaías Figueiró, o qual mantém laços estreitos com o evangelista argentino suprarreferido é manifesto, por exemplo, na própria localização do templo, que se situa em um bairro industrial decadente com altos índices de criminalidade e próximo a zonas de prostituição da região. Ou ainda, no uso de barracas em suas campanhas evangelísticas, onde os casos mais graves são trabalhados por um grupo de pastores especializados e longe dos olhos do público em geral, diferentemente do que se observa nos cultos televisionados da Igreja Universal do Reino de Deus. Do ponto de vista prático, como nas campanhas realizadas pelo Ministério da Salvação de Carlos Annacondia, subjaz a ideia, no caso da Igreja Encontros de Fé, de que o mal está lá fora, em todo lugar, mas que ali, no parque ou campo de futebol - e no templo, no caso da igreja brasileira a que fizemos referência - onde está sendo realizada a campanha, ele é expurgado, combatido, eliminado.

Disso depreende-se que há um certo mimetismo do modelo pastoral utilizado pelo evangelista argentino de modo que, a exemplo deste, o espaço do culto, no caso, brasileiro, e da campanha, no caso argentino, é sacralizado, tornado em campo do senhor, onde, dotados pelos dons do Espírito Santo,

\footnotetext{
${ }^{1}$ Carlos Alberto Annacondia nasceu em 12 de março de 1944 na cidade Quilmes, Província de Buenos Aires. E, segundo o site de seu ministério, conheceu o senhor em 19 de maio de 1979, em San Justo, província de Buenos Aires, em uma Cruzada Evangelística, com o Rev. Manuel A. Ruiz, do Panamá. Seu ministério inicia-se nos anos 80, quando começou a predicar nas vilas emergentes da Grande Buenos Aires e, desde 1981, exerce seu ministério Misión Cristiana Mensaje de Salvación. Sua mensagem já foi ouvida por milhôes de pessoas de diferentes raças dos cinco continentes, estes, das mais diversas condições sociais.
} 
tanto Isaías como Annacondia combatem o mal. Prática essa não muito comum, senão exógena, ao campo evangélico brasileiro de um modo geral. Outro caso que ilustra esse processo de mimetização de práticas religiosas é o caso, por exemplo, da Igreja Batista Renovada - BRASA.

A BRASA, ao entrar em contato com sua congênere uruguaia através do trabalho de missão desenvolvido pelo Ministério por meio do Pastor Luiz Bazerque, leva para terras cisplatinas um modo de se inserir e se relacionar com a sociedade e a política, típicos do pentecostalismo brasileiro. E, a partir desse contato, introduz no campo religioso uruguaio práticas religiosas oriundas do processo de reavivamento sofrido pelo Ministério no Brasil. Eles, os batistas uruguaios, passam, então, a buscar uma maior inserção na política através de apoio e assinatura de listas de candidatos cristãos, do contato com partidos políticos, movimentos sociais, órgãos de governo ligados ao combate à fome e à drogadição, entre outros, algo não muito comum a este segmento naquele país.

Já no tocante às religiões afro-brasileiras, é interessante observar como, por ocasião da Festa de Navegantes, tradicionalmente realizada na cidade de Porto Alegre no dia 2 de fevereiro e promovida pela Cúria Metropolitana de Porto Alegre, elementos oriundos do catolicismo são incorporados às religiōes afro-brasileiras, assim como outros oriundos da mito-práxis afro-brasileira, até pouco tempo atrás, eram parte constituinte da referida procissão. Neste sentido, no que se refere a essa procissão destaca-se que, diferentemente do que ocorria em anos anteriores, quando ainda fazia parte da procissão oficial - organizada pela Cúria Metropolitana - a realização da

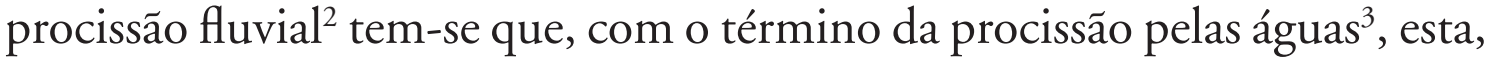

\footnotetext{
${ }^{2}$ Originalmente a procissão fluvial era composta por embarcações de diversos tipos, portes e tamanhos que singravam o Lago Guaíba desde o cais do porto, no centro da cidade, levando imagens tanto de Iemanjá quanto de Nossa Senhora dos Navegantes, que, sincretizadas, tinham nas próprias águas do lago que banha a cidade as homenagens rendidas por religiosos a elas ligados, até a Igreja de Nossa Senhora dos Navegantes. Flores, perfumes, barcos, velas e doces eram, de dentro da própria embarcação, colocados na água em homenagem à Rainha das Águas.

${ }^{3}$ Por determinação impeditiva da Capitania dos Portos.
} 
tornou-se terrestre ${ }^{4}$, de modo que, no que tange às religióes afro-brasileiras, muita coisa mudou.

Isso posto, o que se observa desde então é que uma nova tradição vem sendo construída no interior do campo afro-brasileiro que apesar de ainda se utilizarem (sincretizarem) muitos elementos do catolicismo acabam por, ao seu modo, reinventar a procissão através da construção de um novo itinerário e um novo referente para a mencionada procissão. $\mathrm{O}$ mesmo observa-se no caso da procissão católica que, com o abandono desta por aqueles ligados às religiôes afro-brasileiras em virtude do fim da procissão fluvial, acaba por retirar desta elementos relacionados quase que exclusivamente a mito-práxis afro-brasileira e a Iemanjá.

Figura 1 - Imagem de Iemanjá e Nossa Senhora dos Navegantes no centro do Mercado Público de Porto Alegre, em 2007, no dia anterior à procissão católica.

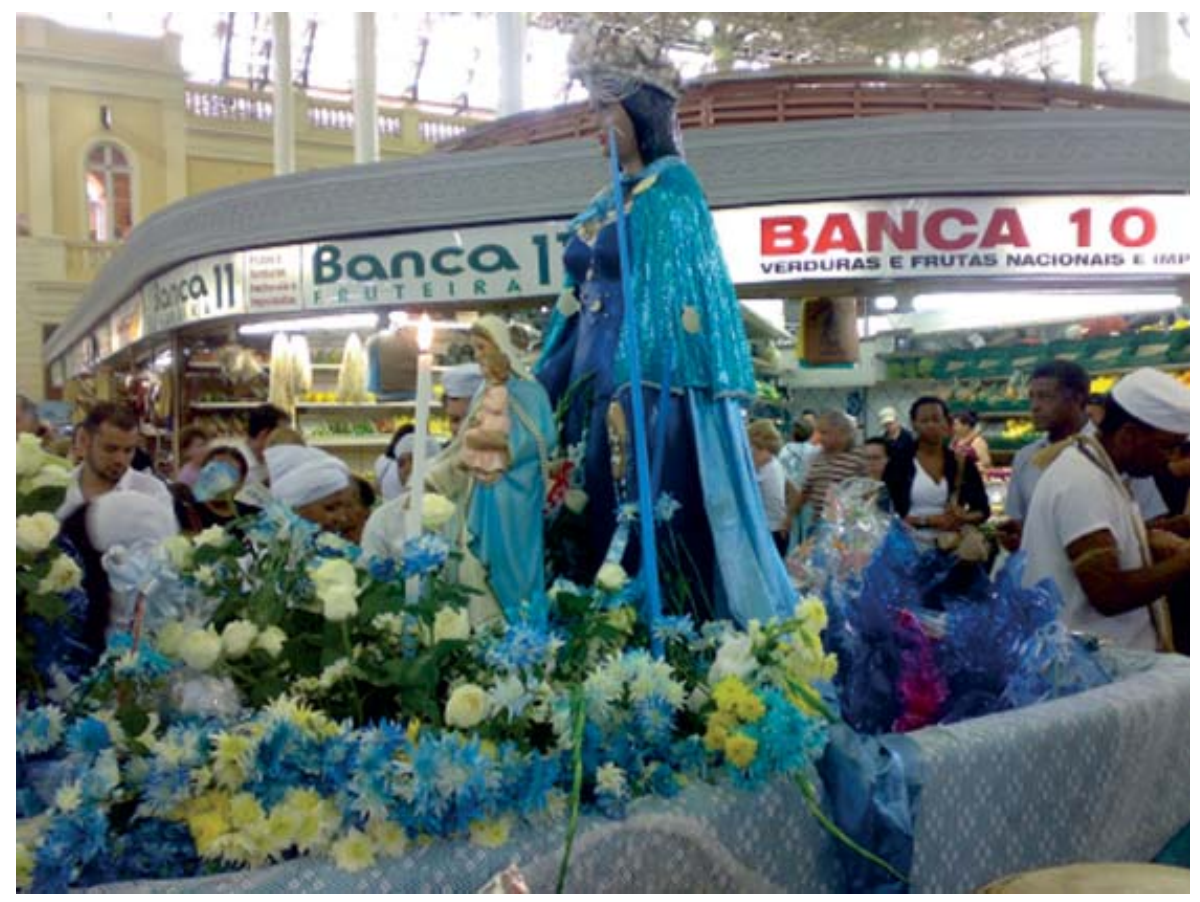

Fonte: Mauro Meirelles (acervo pessoal)

\footnotetext{
${ }^{4}$ Levando a imagem desde a Igreja de Nossa Senhora do Rosário, no centro da cidade, até a Igreja de Nossa Senhora dos Navegantes, esta última, situada no bairro que lhe dá nome.
} 
Ilustra o primeiro caso da realização, no dia anterior ao evento católico, de uma procissão feita exclusivamente pelo povo de santo que, após renderem suas homenagens a Iemanjá no centro do Mercado Público 5 partem, à noite, para a Usina do Gasômetro, onde, dentro de uma pequena embarcação, uma imagem grande de Iemanjá, junto com outra menor de Nossa Senhora dos Navegantes, é colocada na água e os religiosos, ali, rendem suas homenagens à referida orixá/santa. No que se refere à imagem anteriormente apresentada, destaca-se o lugar que nela ocupam a santa e a orixá de modo que, aquela que antes dava nome à procissão, agora, apresenta-se diminuta.

$\mathrm{E}$, apesar do sincretismo entre as duas imagens ser uma constante a partir dos diversos elementos que compóem a imagem que ilustra esse texto, o destaque que será dado à santa ou à orixá na composição desta paisagem imagético-religiosa depende daqueles que lá estão. Dependerá, como exposto por Oro e Anjos (2009, p. 48 e ss.), exclusivamente do modo como elas - a "santinha" e a "santona" - são colocadas em relação por aqueles que ali estão. Já no caso da procissão católica, em virtude da ausência dos afro-brasileiros na procissão, é constante a ausência durante todo o trajeto, de cerca de quatro quilômetros, de pessoas conduzindo, sob suas cabeças, as pequenas embarcaçōes que, antigamente, eram colocadas na água no final da procissão, quando de sua chegada na Igreja de Navegantes, assim como da tradicional barraca de melancias - alimento de Iemanjá - que tipicamente compunha a paisagem religiosa em outros tempos.

Outro exemplo disso são os resguardos que algumas casas de religião de Porto Alegre fazem com relação ao Carnaval, dias em que as casas de santo ficam fechadas. Contudo, como já escrevemos em outro lugar (Meirelles, 2010), tal resguardo não possui fundamento religioso em si, ligado aos

\footnotetext{
${ }^{5} \mathrm{O}$ qual ocupa um lugar central na cosmogonia religiosa deste segmento religioso, uma vez que, segundo o antropólogo Ari Pedro Oro (2007, p. 31), para os seguidores das religiōes afro-gaúchas, o Mercado Público detém um significado simbólico diferenciado pois, as narrativas que circulam nesse meio religioso dão conta de que lá está enterrado, pelo centro do Mercado Público, um assentamento de Bará, entidade que abre caminhos. E, embora os relatos divirjam sobre sua autoria, é certo que, para todos aqueles que praticam a religião dos orixás, esse lugar consiste em uma importante referência religiosa.
} 
preceitos das religiões afro-brasileiras, mas relaciona-se, segundo suas próprias lideranças religiosas, a uma herança do catolicismo. Segundo eles, tal prática advém da forma como, durante muitos séculos, em especial no período que antecede a abolição da escravidão, sob a falsa égide de altares católicos, divindades afro-brasileiras eram cultuadas através de elementos da natureza tributários a cada orixá que era colocado sob o altar. Aos olhos portugueses, era o altar católico que se destacava, enquanto que, na verdade, sob ele estava dissimulado o congá/pegi ${ }^{6}$ contendo o elemento de cada um dos orixás cultuados pelos membros da comunidade africana que à sua frente se reunia para celebrar "os santos católicos dos colonizadores".

Do exposto, importa guardar a forma como esse processo ocorre e, em que medida, o uso de categorias interpretativas tributárias às noções de hibridização, sincretização e mimetização nos serve, pari passu, como referencial analítico para a interpretação da realidade religiosa que compõe o cotidiano das três cidades com as quais nos ocupamos. Realidade essa, imposta tanto pelo processo de colonização das Américas, através da transplantação de uma religião europeia hegemônica quanto pelos fluxos religiosos transnacionais observados ao longo de pelo menos as duas últimas décadas na região. E, da mesma forma, compreender o modo como se dá essa inter-relação entre campos tão singulares como o político e o religioso que, a reboque das religióes neopentecostais e pentecostais assumem um novo desenho e uma nova forma de estruturação impensáveis até poucas décadas atrás, como veremos no item seguinte.

HIBRIDISMO, SINCRETISMO E MIMETISMO: RELIGIÕES FAST RELIGIONE SELF SERVICE RELIGIOSO

Quando referimo-nos a esses três termos - e/ou categorias de análise que dão título a esse tópico - busca-se, através da análise da realidade religiosa

\footnotetext{
${ }^{6}$ Estas duas formas de nominar-se o assentamento dos orixás. A primeira, mais comum entre os umbandistas, a segunda, entre aqueles ligados ao batuque, no caso das religiões afro-gaúchas.
} 
constituída em cada uma das três cidades supracitadas, realizar um movimento de construção/desconstrução de categorias analíticas, muitas vezes, senão em sua maioria, tidas como excludentes no interior do campo da antropologia e sociologia das religióes. Neste sentido, podemos pensar cada uma delas como parte de um processo já constituído - e porque não um instrumento em si a serviço de diferentes grupos/segmentos religiosos que aportam em terras estrangeiras - de dilatação e expansão de diferentes religiosidades para fora de seus países de origem, ou mesmo, para além do próprio campo religioso.

Contudo, antes de passarmos a sua aplicação prática, devemos destacar que, enquanto categorias de análise da realidade social, as três categorias são, antes de mais nada, tipos ideais weberianos que servem para balizar diferentes tipos de análises sejam elas sociológicas, sejam elas antropológicas. São, portanto, um construto mental do pesquisador que, como coloca Weber (1974), não existe em estado puro na natureza. Isso posto, podemos agora, pensar tais categorias em termos de sua utilidade e definir seu escopo analítico.

No que se refere à ideia de hibridização, devemos destacar que esta, é antes de mais nada, uma categoria relacional para a qual convergem elementos oriundos de dois ou mais polos distintos de modo que o híbrido, em si, possui uma carga simbólica passível de mapeamento e que permite situá-lo em relação aos seus referentes primeiros. Contudo, sua existência "de fato" depende dos referentes que o produzem e da distância que esse se situa em relação a estes. A priori, então, como destaca-nos Bruno Latour (2007), é dado que os híbridos têm uma pátria, uma descendência, um campo semântico que o constitui e que é por ele constituído.

Já a ideia de sincretização, pressupõe para além do processo de hibridização, a existência de uma relação de dominação de um sobre o outro (de A sobre $\mathrm{B}$, por exemplo) de modo que, alguns elementos oriundos de A serão valorizados em detrimento de outros oriundos de B, ou vice-versa. Contudo, diferentemente da ideia de hibridização, em que, os híbridos possuem uma pátria e uma existência em si, no processo de sincretização, o sincrético só existe dentro da relação, de modo que, sem a interação entre os elementos 
que o constitui, ele deixa de existir, retornando cada qual ao seu "estado natural" antes de terem sido colocados em relação.

E, por fim, no que se refere à ideia de mimetização importa lembrar que, esta, enquanto categoria analítica - e, diferente das outras duas que capitalizam trocas bidirecionais, em que, elementos de um e de outro são colocados em relação - se relaciona de modo exclusivo à transferência de estruturas estruturantes de um campo a outro, sem com isso alterar a semântica constituinte daquele que se apropria de determinadas práticas externas ao lócus em que este está situado tendo, assim, portanto, uma natureza unidirecional e utilitária. Mimetizar é, portanto, um caminho de mão única, a partir do qual, elementos externos a um determinado campo são utilizados e acoplados a "estruturas estruturadas" anteriormente existentes como "estruturas estruturantes" que visam a garantir a sobrevivência e a própria reprodução daquele que deles se apropria ${ }^{7}$.

Diante disso e voltando ao exposto no item 2, podemos, agora, pensar o processo de transnacionalização e internacionalização religiosas a partir das diferentes estratégias a partir das quais lideranças evangélicas e afro-brasileiras se colocam para fora das fronteiras nacionais. E não menos importante, também, o modo como no interior do campo religioso brasileiro o catolicismo e as religiōes afro-brasileiras se relacionam. Vejamos.

Da necessidade imediata de conquistar espaço no interior do campo evangélico brasileiro e de se dotar de um diferencial em relação a concorrência ferrenha com outras denominações, Isaías Figueiró reinventa sua prática evangelística a partir de Carlos Annacondia. E, com isso, coloca-se como mais uma religião a compor o selfservice de serviços espirituais especializados que compõem o campo pentecostal e neopentecostal brasileiro. Neste sentido, a noção de guerra territorial utilizada pelo segundo serve ao primeiro como um instrumento de trabalho e evangelização onde, a partir

\footnotetext{
${ }^{7}$ Nesse sentido, há de se considerar que, epistemologicamente, no pensamento de Pierre Bourdieu, o conceito de estrutura remete ao de habitus (Bourdieu, 1997), este, entendido como um conjunto de estruturas mentais que são dadas pelo campo, outra noção a ele tributária (Bourdieu, 2007), as quais são utilizadas por aqueles que detêm determinadas posiçôes objetivas no interior de um dado campo para relacionar-se nele e fora dele.
} 
do oferecimento de um serviço espiritual diferenciado este aumenta seu espaço e participação no interior do campo evangélico no qual está situado. O mesmo observa-se quando este, mimetizando a prática política de outras denominações brasileiras, começa a ocupar lugar dentro de partidos políticos dotados de certo caráter confessional, como o Partido Social Cristão, por exemplo.

Já no que se refere à Igreja Universal do Reino de Deus, o que se observa quando de sua chegada e instalação em terras estrangeiras é um duplo movimento que busca de um lado hibridizar, no interior de sua prática teológica, elementos da cultura local e, de outro, sincretizar práticas do catolicismo e das religiōes afro-brasileiras em seus cultos através da utilização de práticas de exorcismo e do uso de objetos e elementos da natureza consagrados pelo pastor. $\mathrm{O}$ primeiro, tributário ao catolicismo, o segundo às religiōes afrobrasileiras, através da realização de correntes espirituais, do uso de sabonetes, óleos, água, rosas, pedaços de tecido, essências etc. que são distribuídas entre os fiéis nos templos em dias de culto, para que, estes, estejam protegidos do assédio e da influência das forças do mal, leia-se exus e pombas-gira, no caso brasileiro, e da magia negra e da bruxaria, no caso do Uruguai e da Argentina. Sobretudo, o que está em jogo para aqueles que se usam desses objetos e correntes realizadas pela Igreja Universal é a resposta rápida a suas necessidades espirituais, ou seja, a fast religion.

Entre os batistas de Montevidéu, a exemplo do que se observa com a igreja Encontros de Fé, que mimetiza as práticas religiosas do evangelista argentino, temos um processo de mimetização, só que, dessa vez, não de práticas teológicas, e sim de formas de relacionar-se com o político e religioso. Estas, características do Ministério BRASA, de modo que o que está em jogo é, sobretudo, um processo de conversão de capital religioso em capital político com vistas a conquista de um maior espaço na cena púbica religiosa uruguaia, em que, devido ao histórico processo de laicização iniciado a cerca de um século e meio atrás, o político foi esvaziado de qualquer conteúdo religioso.

E, por fim, referindo-me às relações entre o catolicismo e as religiões afro-brasileiras, importa destacar o quão importante foi, no caso da última, 
a sua capacidade de absorver elementos de outras religióes e a partir destes montar cadeias de equivalência que garantiram sua coexistência enquanto religião étnica a ser cultuada em um país constituído de uma maioria católica europeia que buscava aqui implantar um modelo de estado confessional, a exemplo de suas metrópoles europeias. Neste sentido, para além desse caráter utilitário e a convivência relacional entre ambas, manifestas em diversos sincretismos presentes nesse evento religioso pontual que é a Procissão de Navegantes, dada a atual conjuntura em que o direito à diferença assume um caráter fundamental e constituinte da modernidade, o retorno às origens, através do processo de africanização/reafricanização das religiōes afro-brasileiras mostra-se como um processo de retorno a sua ancestralidade mítica - a África. Onde a tradição é reinventada a partir do Mercado Público de Porto Alegre e da chegada do Príncipe Custódio ${ }^{8}$ a capital gaúcha.

\section{CONSIDERAÇÕES FINAIS}

No presente texto, buscou-se, a partir da relação que se estabelece entre religiōes postas em contato, através do processo de transnacionalização e internacionalização religiosas, pensar a forma como diferentes estratégias de produção da crença e de reinvenção da tradição são utilizadas por diferentes lideranças religiosas no sentido de expandir seus domínios e campos de

\footnotetext{
${ }^{8}$ Joaquim Custódio de Almeida nasceu em Daomé, numa fortaleza portuguesa chamada São João Batista de Ajudá. Seu nome original era Osuanlele Okizi Erupê. E, nesse sentido, reza a lenda que quando o país foi invadido, em 1897, pela Inglaterra, os ingleses propuseram a ele um acordo: ele poderia viver em qualquer lugar do mundo, custeado pela coroa inglesa, desde que nunca mais pisasse em solo africano. E o príncipe aceitou a proposta e partiu para o exílio, evitando que as mesmas atrocidades promovidas por alemães e franceses em outras regiōes da África se fizessem sentir pelo seu povo. Segundo contanos a tradição oral, tem-se ainda que Custódio veio para o Brasil, estabelecendo-se, num primeiro momento, em Salvador (BA), em seguida no Rio de Janeiro (RJ), chegando, somente anos mais tarde, ao Rio Grande do Sul. Em território gaúcho, estabeleceu-se primeiramente em Rio Grande, seguindo depois para Pelotas e Porto Alegre, onde chegou, em 1901, com 70 anos de idade.
} 
atuação, tanto no Brasil quanto fora dele, em especial, no que se refere ao Uruguai e à Argentina. Neste sentido, algumas constataçóes podem ser feitas.

A primeira delas é que nenhuma das categorias analíticas que utilizamos para a análise deste processo pode ser vista de forma isolada, uma vez que, no interior do campo religioso, conjugam-se interesses dos mais diversos, como é o caso, por exemplo, das Igrejas Batista de Montevidéu e Encontros de Fé de Porto Alegre. A segunda é que, a exemplo do que se observa no caso da Igreja Universal do Reino de Deus e de sua proposta de uma fast religion, dentro do campo evangélico, também, em outros segmentos religiosos não pentecostais, esta estratégia é observada. Dentre estes, destacam-se os carismáticos católicos e aqueles ligados à quimbanda, entre os quais, este modelo começa a se impor com certo vigor, a partir da reinvenção de sua prática religiosa e da emergência de uma nova forma de se relacionar com o corpo e com o divino, seja através da música e da liturgia carismática, seja através do sacrifício de animais e das oferendas feitas pelos adeptos da quimbanda em encruzilhadas, praças e cemitérios.

E, por fim, uma terceira que assevera sobre a própria relação da religião com a modernidade, em que, é cada vez mais importante a satisfação das necessidades imediatas dos sujeitos que buscam na religião um alento para suas preocupações do que a observação dos fundamentos da própria religião. Dito de outro modo, o que se observa a partir do exposto no decorrer do texto é que, a cada dia que passa, normativas teológicas são cada vez mais flexibilizadas em função das necessidades modernas dos fiéis que buscam nas igrejas pentecostais e, também, nas casas de religião uma resposta rápida às suas necessidades, através do self service religioso.

\section{REFERÊNCIAS}

BOURDIEU, Pierre. Razôes Práticas: sobre a teoria da ação. Campinas: Papirus, 1997. - A economia das trocas simbólicas. São Paulo: Perspectiva, 2004. O Poder simbólico. Rio de Janeiro: Bertrand Brasil, 2007. 
CONICET. Primera encuesta sobre creencias y actitudes religiosas en Argentina. 2008. Disponível em: http://www.clarin.com/diario/2008/08/27/um/ encuesta1.pdf. Acesso em: 05 dez. 2012.

DUNDES, Alan. Nationalistic Inferiority Complexes and the Fabrication of Fakelore: A Reconsideration of Ossian, the Kinder- und Hausmärchen, the Kalevala, and Paul Bunyan. Journal of Folklore Research, Bloomington, v. 22, n. 1, p. 5-18, Apr. 1985.

HOBSBAWM, Eric; RANGER, Terence. (Orgs.). A invenção das tradiçōes. Rio de Janeiro: Paz e Terra, 1984.

IBGE. Tabela 1489 - População residente, por cor ou raça, segundo o sexo a religião (Resultados Gerais da Amostra). 2000. Disponível em: http://www. ibge.gov.br Acesso em: 05 dez. 2012.

INE. Encuesta Nacional de Hogares 2006. 2006. Disponível em: http:// www.ine.gub.uy/enha2006/flash/Flash\%206_Religion.pdf Acesso em: 05 dez. 2012.

LATOUR, Bruno. Nunca fuimos modernos: ensayo de antropología simétrica. Buenos Aires: Siglo Veinteuno Editores, 2007.

MEIRELLES, Mauro. Religio et Civilis: (re)inventar a si e ao outro. E-cadernos CES, Lisboa, v. 8, 2010, p. 62-76.

. Para além das fronteiras nacionais: transnacionalização e internacionalização religiosa, novas formas de "ser" e "estar" na política. Debates do NER, Porto Alegre, v. 16, p. 161-182, 2009.

. O Ritual de Libertação e Cura Iurdiano segundo a perspectiva de Mikhail Bakhtin. Debates do NER, Porto Alegre, v. 7, p. 99-108, 2005. ORO, Ari Pedro. Neopentecostais e Afro-brasileiros: quem vencerá esta guerra? Debates do NER, Porto Alegre, v. 1, n. 1, p. 10-36, 1997. 
. O Bará do Mercado Público. In: ORO, Ari Pedro; ANJOS, José Carlos Gomes dos. Festa de Nossa Senhora dos Navegantes, em Porto Alegre: sincretismo entre Maria e Iemanjá. Porto Alegre: Prefeitura de Porto Alegre, 2008. p. 30-51.

PIERUCCI, Flávio. Soltando as amarras: Secularización y destradicionalización. Sociedad y Religión, Buenos Aires, n. 16/17, p. 9-32, 1998.

PRICE, Sally. Arte Primitiva em Centros Civilizados. Rio de Janeiro, Editora da UFRJ, 2000.

SANCHIS, Pierre. Desencanto e formas contemporâneas do religioso. Ciencias Sociales y Religión, Porto Alegre, v. 3, n. 3, p. 27-43, 2001.

SEMÁN, Pablo. Introdução. In: ORO, Ari Pedro (Org.). Religião e Politica no Cone Sul: Argentina, Brasil e Uruguai. São Paulo: Attar, 2006. p. 9-32. SEMÁN, Pablo; MARTÍN, Eloísa. Religião e Política na Argentina. In: ORO, Ari Pedro (Org.). Religião e Política no Cone Sul: Argentina, Brasil e Uruguai. São Paulo: Attar, 2006. p. 33-74.

WEBER, Max. Ensaios de sociologia. Rio de Janeiro: Zahar, 1974. 